\title{
A Delphi study on motivation for ISO 9000 and EFQM
}

\author{
Heras Saizarbitoria Iñaki and German Arana Landín \\ Departamento de Organización de Empresas, Universidad del País Vasco, \\ Spain, and \\ Martí Casadesús Fa \\ Departamento de Organización, Gestión Empresarial y Desarrollo de Producto, \\ Universidad de Girona, Girona, Spain
}

\begin{abstract}
Purpose - The purpose of this paper is to analyse which are the motivations for implementing two of the most important models for Quality Management practice popularized in recent years - ISO 9000 and EFQM models.

Design/methodology/approach - This paper provides a qualitative survey carried out using the Delphi methodology, triangulated with the results of other surveys carried out previously, as well as with the information gathered by means of several in-depth interviews carried out with the experts that participated in the Delphi-panel.

Findings - The paper finds strong consensus among experts of different backgrounds that external factors cause companies to implement the ISO 9000 standard. On the other hand, reasons for implementing TQM systems seem to be more varied.

Research limitations/implications - The research in this paper is limited to Spain; studies in other countries should be conducted to compare the results obtained.

Practical implications - In this paper there is a greater understanding of the motivation to implement ISO 9000 and EFQM based on the opinion of managers, consultants, academic specialists and members of institutions.

Originality/value - The paper finds a new methodology for examining the motivation to implement ISO 9000 and EFQM.
\end{abstract}

Keywords ISO 9000 series, European Foundation for Quality Management, Business excellence,

Delphi method

Paper type Research paper

\section{Introduction}

The aim of this article is to analyse the motivation for QM[1] implementation among Spanish companies and according to the models most commonly used in recent years (ISO 9000 and EFQM[2]) with a new methodology for this research area, the Delphi method.

The final decades of the twentieth century witnessed the forceful emergence onto the business scene of a new culture, movement or paradigm of company management, focussed on the concept of quality. Originally, it was a movement whose impact was limited to the industrial sector, following a natural evolution of models, regulations and techniques included within the traditional sphere of Quality Management (QM). Nevertheless, over the years these initiatives spread and became popularised, reaching almost all sectors of the economy: financial services, education, social services, health

\section{7}

Received January 2004

Revised July 2005 Reliability Management Vol. 23 No. 7, 2006 pp. $807-827$ (C) Emerald Group Publishing Limited 0265-671X 
$\mathrm{IJQRM}$

23,7

808 care, etc. As will be seen, Spanish companies, the object of analysis of this study, have not remained unresponsive to this important rise in quality; quite the contrary, they have positioned themselves among the leaders of this movement.

Regarding the ISO 9000 evolution, it is important to emphasise that, while global in scale, in the early stages these standards spread primarily through the countries of the EU, and especially the UK[3]. For good reason the European Commission established them as a priority objective (Hardjono et al., 1997). By 1996 the countries of the EU had obtained more than 62 percent of the worldwide certificates, of which more than 50 percent had been issued in the UK.

Nevertheless, in that same year spectacular growth began in many countries, among which Spain stands out. This can be seen in Table I, which also shows how, in 2001, the UK continued to be the country with the greatest certification intensity, although it has decreased from 2.82 to 1.57 with respect to the EU mean. On the other hand, Italy has converted itself into the country with the second highest certificate intensity, and during the 1996-2001 period it was the country where the largest number of new certificates were issued.

A concept based on certification intensity with respect to GDP has been elaborated to compare certification levels in each country. Figure 1 provides a graphic illustration

\begin{tabular}{lrrrccr}
\hline & & & & & 2003 & \\
& 1995 & 1999 & 2003 & Percent certif. & Percent GDP & Intensity \\
\hline Austria & 1,133 & 3,421 & 3,204 & 1,31 & 2,17 & 0,6 \\
Belgium & 1,716 & 3,495 & 4,032 & 1,65 & 2,65 & 0,62 \\
Cyprus & 7 & 184 & 328 & 0,13 & 0,13 & 1,03 \\
Czech Republic & 180 & 1,500 & 8,968 & 3,66 & 1,52 & 2,42 \\
Denmark & 1,314 & 1,962 & 935 & 0,38 & 1,45 & 0,26 \\
Estonia & 1 & 77 & 261 & 0,11 & 0,14 & 0,76 \\
Finland & 772 & 2,105 & 2,058 & 0,84 & 1,3 & 0,65 \\
France & 5,536 & 16,028 & 18,007 & 7,36 & 15,21 & 0,48 \\
Germany & 10,236 & 3,015 & 24,889 & 10,17 & 21,77 & 0,47 \\
Greece & 248 & 105 & 2 & 0,82 & 1,87 & 0,44 \\
Hungary & 309 & 3,289 & 7,921 & 3,24 & 1,31 & 2,47 \\
Ireland & 1,617 & 31 & 1,645 & 0,67 & 1,15 & 0,59 \\
Italy & 4,814 & 21,069 & 6,412 & 26,2 & 13,7 & 1,91 \\
Latvia & - & 39 & 75 & 0,03 & 0,2 & 0,15 \\
Lithuania & 2 & 91 & 324 & 0,13 & 0,32 & 0,41 \\
Luxembourg & 48 & 113 & 118 & 0,05 & 0,21 & 0,23 \\
Malta & 12 & 56 & 223 & 0,09 & 0,06 & 1,41 \\
The Netherlands & 5,284 & 1,062 & 10,309 & 4,21 & 4,33 & 0,97 \\
Poland & 130 & 1,012 & 4,127 & 1,69 & 3,84 & 0,44 \\
Portugal & 389 & 1,131 & 4,035 & 1,65 & 1,75 & 0,94 \\
Slovakia & 59 & 560 & 1,231 & 0,5 & 0,61 & 0,83 \\
Slovenia & 99 & 521 & 466 & 0,19 & 0,33 & 0,58 \\
Spain & 1,492 & 8,699 & 33,215 & 13,57 & 8,43 & 1,61 \\
Sweden & 1,095 & 3,786 & 3,107 & 1,27 & 2,25 & 0,56 \\
The UK & 52,595 & 637 & 49,151 & 20,08 & 15,35 & 1,31 \\
EU-25 & 89,088 & 177,758 & 244,749 & 100 & 100 & 1 \\
& & & & & &
\end{tabular}

Source: Prepared from data obtained in ISO reports and information from EUROSTAT $\left({ }^{*}\right)$ Purchasing Power Standards, year 2002
Table I.

Global evolution of the certification process following the ISO 9000 regulations 


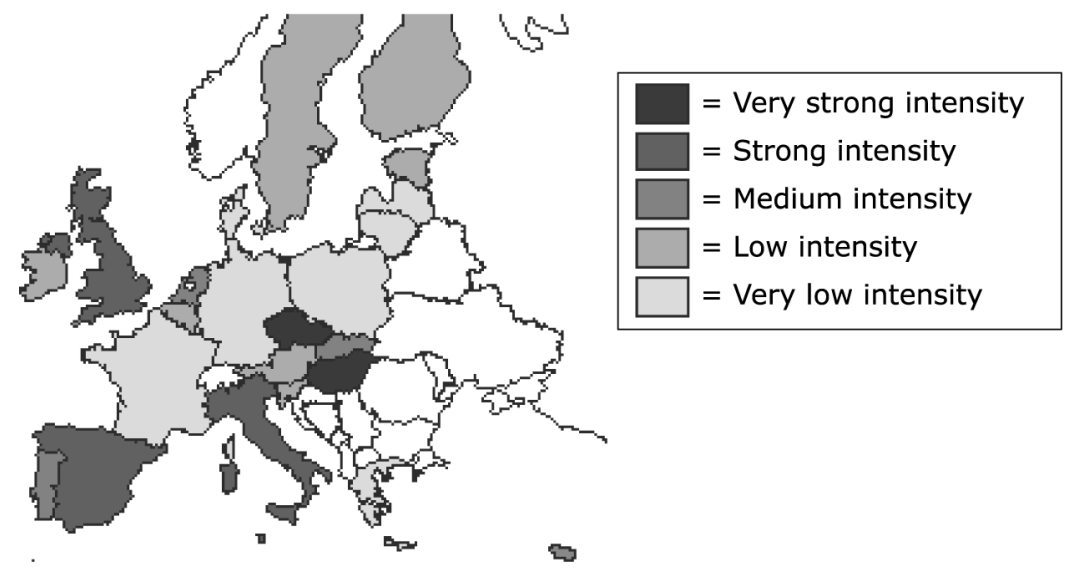

Source: Prepared from data obtained from ISO reports and information from EUROSTAT
A Delphi study

809

Figure 1. Certificate intensity in the countries of the EU

of that indicator, defined as the relation between the percentage of ISO 9000 certificates from each country and its percentage of contribution to the European GDP. An analysis of the indicator provides an initial approximation of the average "level of quality" of companies from each country.

On the other hand, regarding the evolution of the use of the EFQM model, an analysis like the one carried out for the ISO 9000 cannot be completed because it is not a certifiable model and there is no unified record of the number of companies that have implemented it. However, some relative and interesting data can be extracted from the information regarding the recognition granted to it by various national and international organizations.

Standing out at the European level, for example, are the "European Quality Awards" granted by the EFQM for the implementation of TQM. Delving deeper into this analysis, there is an EFQM database with information about companies that have been successful in terms of quality ("Successful Organisations Database"). It is organised into four different categories (from lowest to highest level: "Committed to Excellence", "Recognised for Excellence”, "European Quality Awards Finalist" and "European Quality Awards Winner"). Among the 226 companies within this database there are 41 Greek companies (35 in the lowest category), 31 German companies (20 in the lowest category), 28 companies in the UK (seven in the lowest category) and 28 Spanish companies (seven in the lowest category). Nevertheless, it should be mentioned that if the lowest level category, "Committed to Excellence", is excluded from this database, in the remaining three (higher) categories there would be 21 Spanish companies, 17 companies from the UK, 11 German companies and only six Greek companies. A summary of that information is presented in Figure 2; the database, however, only includes those companies surveyed from the year 2000 onwards.

With regard to the higher-level categories, those corresponding to the "European Quality Awards Finalists" and "European Quality Awards Winners", we should mention that in this database we have found four Spanish companies who have been "European Quality Awards Winners" and a further six who have been finalists. Another fact that highlights the importance Spain has in Europe's quality undertaking 


\section{IJQRM}

23,7

\section{0}

Figure 2.

Organisations recognised by the EFQM as successful in terms of quality between the years 2000 and 2004

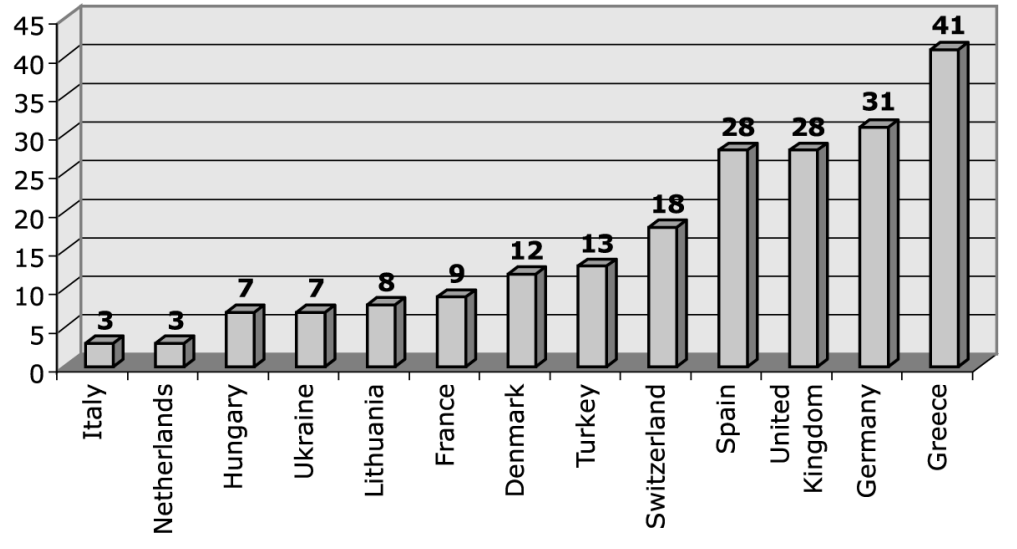

Source: Prepared from the Successful Organisations Database (EFQM)

is that of the 680 organisations that belong to the European Foundation for Quality Management, 48 are Spanish.

Within academia this rise in QM has been extensively analysed through numerous empirical studies. An important part of these empirical studies has been the effort to analyse the main reasons for the implementation of these models. The majority of the studies have been quantitative, based on surveys addressed to managers of companies who have participated in the process of Quality Systems implementation, as will be shown in the next section. However, the studies analysing the motivation for QM in this way include, in our opinion, a possible weakness and methodological distortion of the motivation for the process itself by basing themselves only on the opinions of the managers of the companies involved in the implementation, producing results that might be biased, as has been emphasised by various researchers (see, for example, Wayhan et al., 2002).

For these reasons, in the present study we have considered it necessary to use a methodology that takes into account the opinions of a wide range of experts having a variety of functions in the implementation of QM models. The information thus obtained can be compared and triangulated with information obtained in previous empirical studies carried out with traditional methodology.

\section{Review of the literature}

The academic literature of empirical studies or surveys, which have analysed the motivation for the implementation of quality systems based on the ISO 9000 and TQM models' is very extensive[4].

Table II presents a brief summary of the principal empirical studies carried out around the world in recent years. This summary is not exhaustive and includes only those investigations we have considered most relevant, either for their contributions or for references continually made to them in later studies[5].

Practically all of them are based on what companies' reasons were for implementing one of the most widespread of the QM models, the ISO 9000, leaving aside the study of the implementation of other models, like the EFQM. This may be due to the fact that, as 


Survey
Taylor, 1995, 682
companies in the UK

Internal External

reasons reasons Method Major conclusions

companies in the UK

Santos et al., 1996, 80

companies in Portugal

European Commission

(1994-1996), 500

companies in the EU

Idris et al., 1996, 247

companies in Malasia

Carlsson and Carlsson, 1996, 114 companies in

Sweden

Withers and

Ebrahimpour, 1996,

five companies in the

USA

Meegan and Taylor,

1997, 400 companies in the UK

Erel and Ghosh, 1997, $\quad$ X

73 companies in

Turkey

Buttle, 1997, 1,220

companies in the UK

Jones et al., 1997, 272

companies in Australia

Nottingham Trent

University, 1998, 5,000

companies in the UK
X $\quad \mathrm{X} \quad \mathrm{P}$ The principal reasons for obtaining the certificate are quality improvement linked to pressure from customers and commercial benefits

X $\quad \mathrm{X}$

P The principal reasons are to do with

"company prestige, market strategy" and

"improved competitiveness". Concerns like the "reorganisation of the quality system"

and "pressure from customers" were identified as being of lesser importance

X P/I Around 60 percent of companies obtain the certificate for external reasons (customers, competition, current trends), while a third obtain the certificate for internal reasons

$\mathrm{X} \quad \mathrm{P} \quad$ Among the major reasons are improvements to the management of the company and the chance to start out on the path to TQM

$\mathrm{X}$

$\mathrm{P} \quad$ The main reason for obtaining the certificate is to start out on the path to TQM

X $\quad \mathrm{X}$

$\mathrm{P}$

Certification was obtained mainly because of customer demands, for being an objective of the corporation and to improve quality and competitiveness

X $\quad \mathrm{P}$ These authors argue that it is inevitable that managers look at ISO 9000 standards from a negative point of view, as long as this remains one of companies' major reasons for obtaining certification. The result of this is that managers do not fully involve themselves in the project

P Most frequently cited reasons: "a chance to implement a quality system" and "a step towards TQM". Factors like requirements for exporting to the EU and customer

requirements are given less importance
P Marketing-related concerns are secondary

$\mathrm{X}$ motivating factors for the obtaining of the certificate, while both profitability and process improvement are considered of greater importance

X $\quad \mathrm{P} \quad$ Their main conclusions from this investigation are that companies obtain certification for external reasons and due to customers' demands

X

P Around 60 percent obtained certification to improve the efficiency of the company, while only 39 percent did this in response to pressure from customers.

\section{A Delphi study}

811 
IJQRM

23,7

812

\begin{tabular}{llc}
\hline Survey & $\begin{array}{l}\text { Internal } \\
\text { reasons }\end{array}$ & $\begin{array}{c}\text { External } \\
\text { reasons }\end{array}$ Method Major conclusions \\
\hline
\end{tabular}

Tang and Kam, 1999,

19 companies in Hong

Kong

Beattie and Sohal, 1999, X

50 companies in

Australia

Leung et al., 1999, 500

companies in Hong

Kong

Lee and Palmer, 1999,

121 companies in New

Zeeland

Lipovatz et al., 1999,

111 companies in

Greece

Huarng et al., 1999, 376

companies in Taiwan

Acharya and Ray,

2000, 100 companies in

India

Sohal and Terziovski,

2000, 395 companies in

Australia

Yusof and Aspinwall,

2001, four companies in the UK

Singels et al., 2001, 192

$\mathrm{X}$

companies in Holland
X $\quad \mathrm{X}$

X

$\mathrm{X}$

X

X

$\mathrm{X} \quad \mathrm{P}$

In this type of company, the main reason for obtaining certification is the obligation for this imposed by the country's governing bodies for securing public contracts

$\mathrm{C}$ The main reason is to secure a competitive advantage and to initiate a TQM process and a continual-improvement process. Demands from customers are of secondary importance

P They conclude that companies do obtain certification in response to customers' demands, but that internal improvements are also an important reason

X $\quad \mathrm{X} \quad \mathrm{P}$

Their main conclusion is that the smaller companies are, the more likely they are to implement ISO 9000, due to both internal and external reasons. There are significant differences in implementation according to company size.

$\mathrm{X} \quad \mathrm{P}$ The main reason for obtaining certification is a response to both internal and external customers' demands, particularly in companies in the chemicals sector

P The improvement of companies' working procedures and of their external image is the main reason for obtaining certification

$\mathrm{P} \quad$ The main reason companies have for obtaining certification is to continually and globally improve their management system. It is interesting to note that customers' demands come in last place in this investigation

$\mathrm{P} \quad$ A fall in the number of companies implementing TQM systems was encountered probably due, according to the authors, interestingly and perversely, to the effect of the rise in ISO 9000 certification

$\mathrm{P} \quad$ The main reasons they have for implementing Total Quality Management Models is to improve the company's management system. Another reason is to adapt their products and services to their customers' requirements

$\mathrm{P} \quad$ One of the main reasons is to improve the company's competitiveness and the comfort of having a system that safeguards this improvement.

Table II. 


\begin{tabular}{|c|c|c|c|c|}
\hline Survey & $\begin{array}{l}\text { Internal } \\
\text { reasons }\end{array}$ & $\begin{array}{l}\text { External } \\
\text { reasons }\end{array}$ & Method & Major conclusions \\
\hline $\begin{array}{l}\text { Leonard and McAdam, } \\
2002,19 \text { companies in } \\
\text { the UK }\end{array}$ & $\mathrm{X}$ & $\mathrm{X}$ & $\mathrm{C}$ & $\begin{array}{l}\text { The implementation of TQM models is } \\
\text { largely attributable to corporate decisions } \\
\text { that use them as a means to achieving } \\
\text { strategic objectives }\end{array}$ \\
\hline $\begin{array}{l}\text { Gotzamani and } \\
\text { Tsiotras, 2002, } 84 \\
\text { companies in Greece }\end{array}$ & $\mathrm{X}$ & & $\mathrm{P}$ & $\begin{array}{l}\text { In this investigation, demands from } \\
\text { customers and the fact that competitors } \\
\text { have this certification are the two least } \\
\text { important reasons of all those analysed }\end{array}$ \\
\hline $\begin{array}{l}\text { Boulter and Bendell, } \\
\text { 2002, 1,066 companies } \\
\text { in the UK }\end{array}$ & $\mathrm{X}$ & $\mathrm{X}$ & $\mathrm{P}$ & $\begin{array}{l}\text { In an investigation in which a large number } \\
\text { of companies participated, } 72 \text { percent of them } \\
\text { considered the improvement of the product or } \\
\text { service one of the main reasons. Purely } \\
\text { commercial reasons came in second place }\end{array}$ \\
\hline $\begin{array}{l}\text { Salaheldin, 2003, } 83 \\
\text { companies in Egypt }\end{array}$ & $\mathrm{X}$ & $X$ & $\mathrm{P}$ & $\begin{array}{l}\text { Companies' main reasons for implementing } \\
\text { TQM systems come in this order: an } \\
\text { undertaking by management to improve } \\
\text { management quality, an attempt to increase } \\
\text { exports abroad, an attempt to attract foreign } \\
\text { investment and an attempt to improve } \\
\text { productivity }\end{array}$ \\
\hline
\end{tabular}

Source: Prepared from the published studies presented in the table. Note: (P) Postal survey to managers; (C) Case study; (I) Interviews

Table II.

has been argued in specialist literature (Haversjö, 2000), since a database of companies adhering to the ISO 9000 exists and registers of companies implementing the TQM does not, it is easier to carry out empirical studies on the former.

As can be seen in the table, most of the studies were quantitative and based on surveys directed at managers; and most of the surveys were addressed specifically to managers and/or staff responsible for quality control in the companies surveyed.

These studies, in our opinion, are possibly weakened and methodologically distorted by basing themselves only on opinions about the effects of the process of the company managers who had participated in the implementation process of the quality systems. As a result of this possible bias, for example, on another important research line in this field, the research line where the impact of QM models on company results is analyzed, the use of commercial economic and financial databases as sources of objective information has grown in recent years (Haversjö, 2000; Wayhan et al., 2002; Heras et al., 2002, 2004; Dimara et al., 2004).

For these reasons, in the study summarised in this paper it was considered necessary to use a method taking into account the opinions of experts responsible for a variety of functions in the QM implementation process, in order to analyse results in a more wide-ranging way.

\section{The Delphi method}

The Delphi method, despite being a frequently used research technique in fields like medicine or sociology, has not been used very often in the area of knowledge of 
IJQRM

23,7

814 company organization, in general, and in the field of QM studies, in particular (for our knowledge this is the first time that this methodology is used in this field). In the early stages, its use was focussed on studies of market technology, which is why it has been associated with this study, although its potential is much greater. (In this respect, the examples of practical applications of the Delphi method reported in Linstone and Turoff, 2002 are very interesting). In fact, this method has been applied from the beginning in the analysis of questions related with education, public administration or other economic and business issues (Helmer, 1966; Campbell, 1966). Currently, according to our knowledge of the field of QM in Spain, the use of the method is growing little by little (see, for example, Rodríguez Antón et al., 2004).

The academic literature containing the methodological foundations of this method of research is extensive. Internationally, various monographs coordinated by Linstone and Turoff (2002) and MacCarthy and Atthirawong (2003) stand out. Next we will try to carry out a summary of the methodological bases of the Delphi method, as well as look at its strengths and weaknesses.

According to the classic definition, the Delphi method is a general way of structuring the group communication process and making it effective enough to allow a group of individuals, functioning as a whole, to deal with complex problems (Linstone and Turoff, 1975, 2002). Consequently, as MacCarthy and Atthirawong (2003) point out, it is a systematic process, which attempts to obtain group consensus resulting in much more open and in-depth research, since each member of the group contributes new aspects of the problems to be researched during the post-research phase. The renowned sociologist Castells (1999) claims that one of the bases of the Delphi techniques is rooted in the fact that they are more socially representative than statistics based on opinions of experts in the field under investigation. Nevertheless, forming the foundation of this social representation are large numbers of quantitative studies in which specific agents/platers from the institutions studied participate as representatives of a specific organization (a business, for example).

Reid (1988) points out that one of the keys to success in this type research is appropriate selection of panel members: they should be selected for their capabilities, knowledge and independence. In addition, it is advisable to form these groups with a minimum of seven and a maximum of 30 members (MacCarthy and Atthirawong, 2003; Denzin and Lincoln, 1994; Linstone and Turoff, 1975; Landeta, 1999), even though studies have been carried out with much more numerous groups of hundreds of people, and one study was even done with several thousand people in Japan. Some authors have pointed out, however, that in the larger groups many of the experts do not demonstrate sufficient knowledge or capability and, in addition, in these cases the proportion of experts who prematurely withdraw from the research increases (Reid, 1988; Landeta, 1999). To avoid these withdrawals, it is essential that the experts selected receive information about the objectives of the study, the estimated time required for their participation, the potential of the research and possible benefits they can obtain by participating in it, regardless of the means of communication used to contact them.

On the other hand, to achieve effective communication, it is necessary to avoid the dominant influence of any one member of the group over the others. The Delphi method, according to numerous authors, manages to reduce this danger (Ray and Sahu, 1990; Klassen and Whybark, 1994; Green and Price, 2000; MacCarthy and 
Atthirawong, 2003). To accomplish this, the participants must not know the identities of the other members of the group when expressing their opinions.

Once the group of experts is created, a communication process is established as indicated in Figure 3.

Another basic aspect of the successful use of this methodology is rooted in the writing of the questions to be included in the different questionnaires. They must be clear and concise, and correctly understood by the experts. In the first phase, it is advisable to begin with open-ended questions, so as to extract from their responses the items and questions upon which the continuation of the work will be based. In the next phase, the questions should be directed towards the assessment, the hierarchical comparison of items, or even towards specific quantitative estimations. That is, it must be possible to measure the results of the surveys with established criteria. Once the responses have been received, the work with the results begins. As has been previously pointed out, the objective of the successive questionnaires is to try to diminish any dispersion of opinions and specify the average opinion agreed upon. Therefore, when the responses are received the group coordinator begins to add up the various individual estimations and extracts from them a measurement of the central tendency of the distribution, generally the median, which is then accepted as the group response. In the questions permitting it, the interquartile range of the responses is also estimated, as a measurement of its dispersion (Landeta, 1999). Once the results of each survey have been analysed, it will be decided whether another survey is necessary or, on the contrary, whether a high degree of consensus has already been reached.

In case another enquiry is necessary, the experts are normally sent information about the median and the interquartile range together with their previous, individual responses. Furthermore, additional information required or provided by one or more of the experts is occasionally attached or simply made available by the group coordinator if it is considered to be of interest and related to the purpose of the investigation. In light of this new information, the experts are requested to reconsider their first estimations, if they consider it necessary. The process is repeated until the responses stabilise, that is, when the median shows practically no oscillation and the interquartile space stops

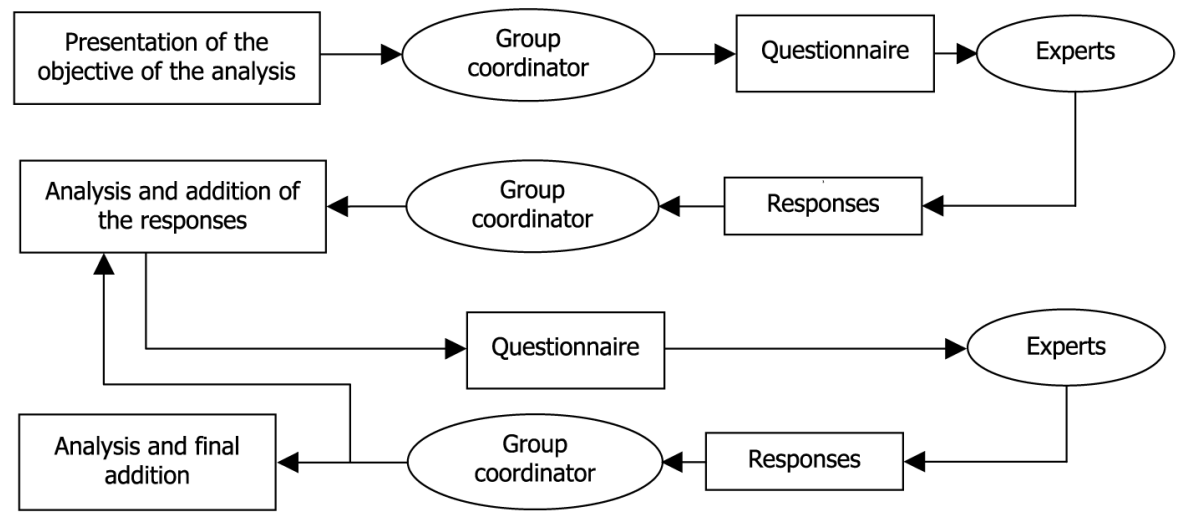

Source: Adapted from Landeta (1999)

\section{A Delphi study}

815

Figure 3. Communication process in a Delphi study 
IJQRM

23,7

816 getting narrower. This indicates that, following an anonymous exchange of information, maximum consensus has been reached (MacCarthy and Atthirawong, 2003).

There are several important advantages or strengths to this method (Linstone and Turoff, 1975; Landeta, 1999; Denzin and Lincoln, 1994). First, the collective knowledge of the group will always be superior to the knowledge of even the best-prepared participant, since the knowledge of all the participants is mutually complemented. Secondly, with this method the opinions of each one of the members can be contrasted with the others. And, finally, there are more factors serving as objects of the study, given that each expert contributes to the general discussion ideas about the topic as seen from the viewpoint of a specific field of knowledge. There are, on the other hand, also weaknesses. Like all qualitative research methods, the Delphi method has been the focus of much criticism from the field of academic research where the use of quantitative methods dominates. Generally speaking, the scientific foundations of this method have been criticised (see, for example, Woudenberg, 1991; and Sackman, 1975) and, more specifically, criticisms have been made of the subjectivity inherent in a method which places such high significance on the opinions expressed by a small group of people.

Much remains to be discussed, but that discussion would obviously extend beyond the objectives of this article. We will limit ourselves to pointing out, as a means of reflection, that the limitations created by this subjectivity and this dominance of value judgements, in other word the regulatory bias of this research method, can also be attributed, to a great extent, to the conventional use of quantitative methodologies in our field, only very recently the focus of any criticisms. For example, data for a large part of the empirical research in this field are obtained from surveys given to managers or people responsible for quality. These data can also be made to look ridiculous, due to limitations of the use of questionnaires as tools, or to the possible biases referred to previously, among other factors now coming out in the literature (see, for example, Boys et al., 2004; and Wayhan et al., 2002). It is a limitation that is well known to researchers in the field of management and becoming appreciated more and more by prestigious researchers and editors.

\section{Development of the empirical study}

This study, carried out between May of 2003 and June of 2004, takes into account a series of precedents, which, albeit in a summary way, are important to highlight. By the time of the planning stages, the authors had already had a certain amount of research experience carrying out empirical studies analysing QM system implementation processes and results (see, for example, Casadesús et al., 2001; Heras, 2001; and Heras et al., 2002). These studies were focussed on the analysis of implementing the ISO 9000 standards using quantitative techniques, questionnaires directed at the managers of certified companies (Casadesús et al., 2001; and Heras, 2001), and commercial economic and financial databases (Heras et al., 2002, 2004). Likewise, Heras (2001) carried out a quantitative study in the Basque Country, an Autonomous Region of Spain, in which not only managers but also others involved in the ISO 9000 implementation process (workers, clients, suppliers, certifying bodies and consultancy firms) were involved. However, due to the limited participation of some of those involved, the established goals were not achieved (Heras, 2001).

In order to carry out this study of the ISO 9000 standard, which had experienced a spectacular increase in use, as well as of the implementation of the EFQM model, one of 
the most widely used models internationally and the most frequently analysed in academic literature (Van der Wiele et al., 2000), it was considered appropriate to use a qualitative investigative technique, which would complement and triangulate these results along with the methodology of previous research. Thus, a panel of experts was formed to carry out a Delphi-type research project to analyse the results of both the ISO 9000 standard and the EFQM model. Participating in the panel of experts (formed in May-June of 2003) were 27 QM professionals and specialists from the Basque Country: company managers, consultants, certifiers, academic specialists[6], assessors and members of institutions like Euskalit and the Knowledge Cluster[7]. The study was focussed on the Basque Country because it is the region of Spain where QM has experienced the greatest boost and development (Heras et al., 2003), and because the results obtained can be extrapolated to other regions of Spain, evidence of which has been presented in previous research efforts by the same authors (Casadesús et al., 2001; Heras, 2001). The assessment work carried out by the Euskalit Foundation[8] was crucial for the formation of the panel of experts (see Table III).

\begin{tabular}{|c|c|c|}
\hline Name & Activity & Selection criteria \\
\hline J.E. & Manager of Balzers-Elay & A group of experts was formed of high-level \\
\hline I.U. & Manager of Group Egaña & managers with experience in the \\
\hline A.R. & Manager of ACICAE & implementation of QM systems. They came \\
\hline J.M.O. & Manager of Irizar & from companies with a variety of \\
\hline J.M.C. & Manager of Naturcorp & characteristics and objectives that had \\
\hline M.C. & Manager of MQM Corporation & $\begin{array}{l}\text { reached different levels of QM system } \\
\text { implementation }\end{array}$ \\
\hline G.G. & Consultant from Easo Consultants & They formed part of a group of six \\
\hline J.M.A. & Consultant from Sayma Consultants & consultants with extensive experience in the \\
\hline & Consultant from Ibarzabal Associates & implementation of QM systems. Some of \\
\hline J.M.B. & Consultant from Dirección Integral y & them were from large consultancy agencies \\
\hline M.O. & Desarrollo & while others were from smaller agencies \\
\hline I.I. & $\begin{array}{l}\text { Consultant from OPE Consultants } \\
\text { Consultant from HOBEST }\end{array}$ & that employed different working methods \\
\hline G.S.A. & Auditor from AENOR & Also on the panel were a group of auditors \\
\hline M.M. & Auditor from DNV & belonging to the four principal accredited \\
\hline P.S. & Auditor from Bureau Veritas & bodies operating in the Basque Country, \\
\hline J.M. & Auditor from TÜV & $\begin{array}{l}\text { which had issued } 75 \text { percent of the ISO } 9000 \\
\text { certificates }\end{array}$ \\
\hline M.B. & Assessor from Euskalit & Also participating were four assessors from \\
\hline E.M.L. & Assessor from Euskalit & Euskalit with experience in EFQM model \\
\hline I.M.L. & Assessor from Euskalit & implementation assessment in a variety of \\
\hline J.M. L.G. & Assessor from Euskalit & types of companies \\
\hline R.E. & Specialist from academia & In addition, a group of specialists from the \\
\hline J.M.B. & Specialist from academia & field of academia, prestigiously renowned \\
\hline F.P. & Specialist from academia & for their work in both the implementation \\
\hline D.E. & Specialist from academia & and dissemination of QM \\
\hline S.L. & Manager of Euskalit & Finally, the panel also contained \\
\hline M.U. & Manager of Euskalit & institutional representatives of \\
\hline I.L. & Manager of the Knowledge Cluster & $\begin{array}{l}\text { organisations promoting QM in the Basque } \\
\text { Country }\end{array}$ \\
\hline
\end{tabular}

Source: Prepared by the authors

\section{A Delphi study}

817
Table III.

Members of the panel of experts 
IJQRM

23,7

818
An initial questionnaire was sent to the panel of experts. Included in it was a series of very open-ended questions, based on the experience of the researchers and the contributions collected from the summarised literature. The pilot version of the questionnaire was reviewed and corrected by an assessment group formed by a manager, a consultant, an assessor and two academics with extensive research experience.

In principle, as had been gathered from reading the specialised literature on the method, two rounds of consultations with the experts were anticipated, with the possibility of a third round, if the consensus reached was not adequate. Once the questionnaires had been circulated twice, group consensus was high, and the circulation phase was considered, finished. The procedure was then repeated several more times until the responses were refined and a convergence of responses over the occurrence of a series of events was arrived at. Likewise, and as can be seen in the literature, in each round the median was calculated as a measurement of concentration and the interquartile distance was calculated as a measurement of dispersion of the various assessments carried out by the experts. This, in turn, formed part of the information, which was subsequently provided to the experts in order to reach consensus.

Once the study and the analysis based on the contributions of the panel were concluded, in the autumn of 2003, a new complementary phase of the research was initiated, in which in-depth interviews with the experts who participated in the panel were carried out. These interviews were structured according to the questionnaires used by the panel, with the aim of qualifying and completing some of the commentaries collected throughout the research period. This triangularization to improve results had already been recommended in the literature (Dootson, 1995). This phase of the study, arduous although fruitful, concluded in June of 2004.

\section{Results of the empirical study}

A synthesis of the results of the empirical study carried out is presented below. An analysis of the motivations for the implementation of QM models is presented in two different parts: the first makes reference to an analysis of the motivations for ISO 9000 implementation, while the second analyses the motivations for EFQM implementation.

In phase one, experts were asked open questions on the reasons companies have for implementing ISO 9000 and TQM according to the EFQM model. Already in this initial phase there was a strong consensus on the types of reasons or items to which the experts attributed most importance, although, as we shall see, in the valuation of these items there was not such a strong consensus.

As regards the ISO 9000 standard, Figure 4 shows the quartile average of the valuations made by experts on a Likert scale [1.5]. The panel members consider that the main reason companies have had for implementing the standard has been pressure or demands from customers, this view being supported by several recent international investigations carried out by means of surveys.

It is significant that the group's participants agree unanimously, since differing perspectives might be expected on this matter from experts from different backgrounds. Likewise, the different subgroups all agree that the improvements certification makes to the company image is the second most important reason why companies obtain certification. With respect to this fact, an experienced consultant explained to us that:

... companies consider certification a chance to improve their image, and therefore, once they have obtained certification, they publicise this fact to the point where, in many cases, they use it as if it were a product label, despite the fact that legislation exists that expressly prohibits this. 


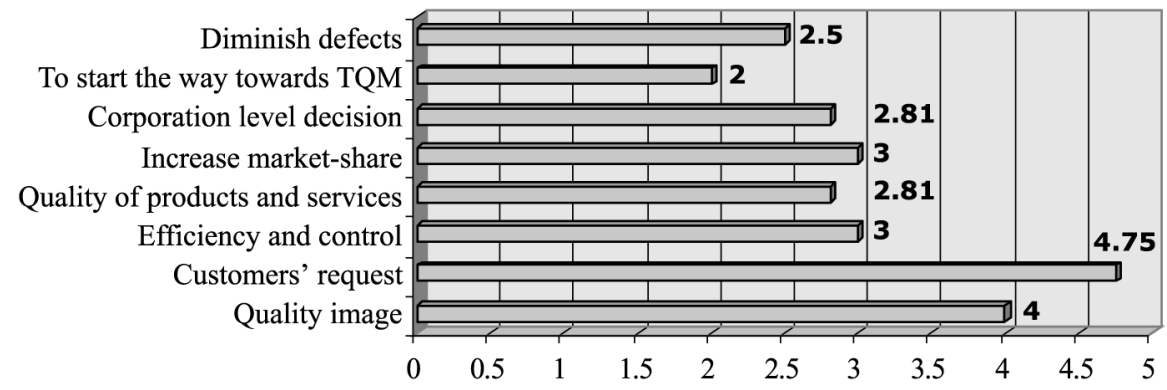

Source: Prepared by the authors
A Delphi study

819

Figure 4.

Reasons for implementing

ISO 9000

The panel's opinion is that companies obtain certification more for external reasons than for internal ones. We must remember that such internal reasons are considered of greater importance by a large number of documented studies, as can be observed in Table II, although most investigators have concluded that the influence is clearly either mixed or dominated by internal reasons. In this way we can state that in studies based only on the opinion of management the main trend established that internal questions, related to improvements in internal efficiency, were those cited as the most important factors influencing the decision to implement ISO 9000. However, in this study, the panel relegated these reasons to second place with a strong consensus among most subgroups, even if some managers attribute primary importance to them.

Besides this, theoretical literature has generally affirmed that ISO 9000 certification constitutes the first step in implementing TQM models in the future, and that this has, in fact, been one of the main motivating factors. This has been confirmed by several empirical studies. In our study this factor was given importance by a few experts only. With regard to this, a leading company manager explained to us that:

... they are two different ways to interpret Quality Management and these must be dealt with separately because, although they may have certain common objectives, the paths to follow are separate.

As regards the reasons for implementing TQM, and in particular for implementing the EFQM model, from our analysis we insist that there is no strong agreement between the different subgroups on main reasons, as can be seen in Figure 5. In general, responses attach important weight to the influence of external factors on the implementation process for TQM models, although internal factors are given greater importance than in the case of ISO 9000.

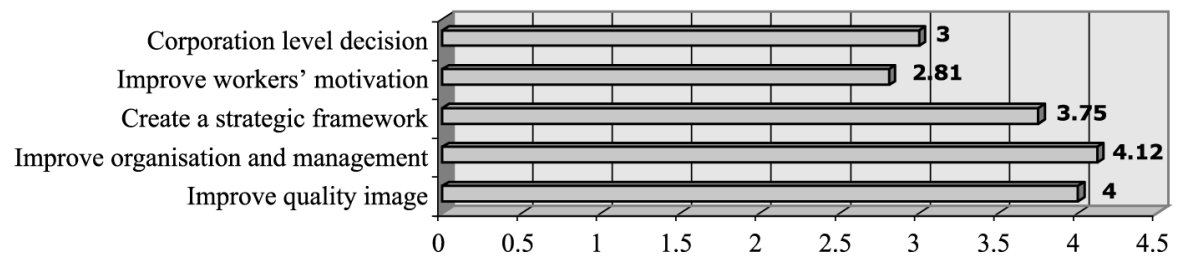

Figure 5. Reasons for implementing TQM models

Source: Prepared by the authors 
IJQRM

23,7

820
The different subgroups all point out that two of companies' major motivations are linked to internal improvements, with overall concerns like improvements in the organisation and management of the company and the opportunity to give the company a strategic framework within which to evolve. Besides this, the experts also attached significant importance to reasons linked to improving the quality image the company portrays to the market.

Actually, an interesting consensus does exist between the experts' subgroups. Thus, company managers state that the basic reason lies in "an attempt to improve the system of company management”. One manager told us:

The reasons the EFQM and ISO models are implemented are very different. The ISO is implemented in the company from and for the outside. The EFQM model, on the other hand, is implemented by and for the company itself. It is implemented to make improvements, but because there is an internal need for improvement.

Along the same lines, assessors of TQM models state that the basic reason is an attempt by companies to "set up a process of continual improvement". The following comment sums up the opinion of this subgroup perfectly:

Many of the companies who get involved with the implementation of the EFQM model have implemented improvement programmes before (for example 5S, improvement teams), and implement this model as a new strategic framework for improving the company.

Lastly, it is worth mentioning that consultancies, certifying organisms and institutions all point to "institutional development" as the principal motivating factor, a sentiment fully shared by one of the consultants on our panel:

The extent to which prizes are being awarded to companies, both by Escalate and mainly by the EFQM foundation presages a new wave of companies implementing the EFQM model.

Besides this, the panel of experts finds clear differences in the motivations and actions of two large groups of companies. This differentiation was very clear and very pronounced, shared by a strong consensus in the post-survey interviews we carried out. Thus, one consultant on the panel told us in the interview:

There are two very different types of company. On the one hand, we have the companies who implement the TQM with the aim of improving their system of management, but on the other hand the principal objective of the great majority seems to be the external recognition that is obtained once they have publicised the goals they have achieved.

This differentiation is interesting, set next to subsequent empirical studies because, as we know, in the literary documentation of empirical studies based on the opinions of managers there is no consensus in establishing the principal motivating factors for implementing TQM models (see, for example, Sun, 1999; Mathews et al., 2001).

In summary, Tables IV and V contain a succinct summary of the most noteworthy opinions on reasons companies have for implementing the two QM models analysed: The assurance standard ISO 9000 and the EFQM TQM model. These opinions are not those that have enjoyed the strongest consensus, but those that we feel deserve attention, as they summarise the various contributions of the panel's different subgroups. 


\begin{tabular}{|c|c|c|c|}
\hline \multirow{2}{*}{$\frac{\text { Agent }}{\text { Managers }}$} & \multirow{2}{*}{$\begin{array}{l}\text { Opinion } \\
\text { "In industrial sectors customers demands for the ISO } \\
\text { to be implemented has been the fundamental factor." }\end{array}$} & \multicolumn{2}{|c|}{ Degree of consensus } \\
\hline & & $\begin{array}{l}\mathrm{D} 0000 \\
\mathrm{C} 00000 \\
\mathrm{~A} 0000\end{array}$ & $\begin{array}{ll}\mathrm{A} \\
\mathrm{Aa}\end{array}$ \\
\hline Managers & $\begin{array}{l}\text { "The need to improve and be more competitive has } \\
\text { been behind many of the decisions to implement." }\end{array}$ & $\begin{array}{ll}-10 \\
000 \\
000\end{array}$ & $\begin{array}{l}\text { A } \\
\text { As }\end{array}$ \\
\hline Assessors & $\begin{array}{l}\text { "There has been an ISO boom. It has become a trend } \\
\text { in almost every sector, and the image effect and } \\
\text { trend effect have had a lot to do with it." }\end{array}$ & $\begin{array}{l}\text { M००००० } \\
\text { C००००० } \\
\mathrm{Au} \bullet \bullet \bullet ० ०\end{array}$ & $\begin{array}{l}\mathrm{A} \odot \\
\mathrm{As} \\
\mathrm{Mi}\end{array}$ \\
\hline Consultants & $\begin{array}{l}\text { "If my direct competitor does it, I have to do it too. } \\
\text { This has been the main reason." }\end{array}$ & & \\
\hline Consultants & $\begin{array}{l}\text { "State grants to subsidise implementation costs (for } \\
\text { example, consultancy fees) have been an important } \\
\text { factor in motivating companies. With } 80 \text { percent of } \\
\text { costs subsidised, many companies have decided to } \\
\text { go for it" }\end{array}$ & $\begin{array}{l}\text { M००००० } \\
\text { C००००० } \\
\text { Au०00०० }\end{array}$ & $\begin{array}{l}\text { A } \\
\text { As } \\
\mathrm{Mi}\end{array}$ \\
\hline Auditor & $\begin{array}{l}\text { "We implemented ISO partly to break into European } \\
\text { markets and so that someone from outside the } \\
\text { company could assess its management and capacity } \\
\text { to improve." }\end{array}$ & $\begin{array}{l}\text { M००००० } \\
\text { C००००० } \\
\mathrm{Au} \bullet 0000\end{array}$ & $\begin{array}{l}\text { A } \\
\text { As } \\
\mathrm{Mi}\end{array}$ \\
\hline $\begin{array}{l}\text { Academic } \\
\text { specialists }\end{array}$ & $\begin{array}{l}\text { "This tool has become very trendy and has had } \\
\text { enormous media coverage, which is why it has } \\
\text { become a very important motivating factor for } \\
\text { managers. This was one of the main reasons why we } \\
\text { implemented it." }\end{array}$ & $\begin{array}{l}\text { M००००० } \\
\text { C००००० } \\
\mathrm{Au} \bullet 0000\end{array}$ & $\begin{array}{l}\text { A๑ } \\
\text { As@ } \\
\text { Mior }\end{array}$ \\
\hline
\end{tabular}

Members of institutions

Source: Prepared by the authors

\section{A Delphi study}

821
Table IV.

Summary of noteworthy opinions on the ISO 9000 standard

\section{Conclusions and contributions}

Using a research methodology that is new to empirical studies on QM, this study has analysed the reasons for implementing the ISO 9000 and the TQM EFQM model. Not only have we applied the Delphi model with all its pros and cons already analysed in section 3 of this article, but we have also applied it forming a panel of experts with subgroups of different profiles, with the idea of enriching the opinions collected, completing them with structured personal interviews. We believe the methodology to be interesting both for academicians and practitioners, not only for validating statements gathered from the theoretical and practical literature, but also for collecting new points of view and proposals that could be the objects of future study.

With regard to the reasons, we confirm - and there is a strong consensus among experts on this, independent of their backgrounds (managers, auditors, consultants ...) - that external factors cause companies to implement the ISO 9000 standard. On the other hand, reasons for implementing TQM systems are more varied. Here, there seem 
IJQRM

23,7

822

Managers

Assessors

Assessors

Consultants

Academic

specialists

Table V.

Summary of noteworthy opinions on the EFQM model

\begin{tabular}{ll}
\hline Agent & Opinion \\
\hline Managers & "The EFQM model was implemented as it is a \\
& $\begin{array}{l}\text { framework that is becoming more and more used } \\
\text { and recognised as being a company planner and } \\
\text { manager." }\end{array}$
\end{tabular}

"Because it is a good model for managing your company and also, and this is very important, it is widely recognised both in Spain and in Europe."

"Promotion of the model by public authorities has had a lot to do with it. Without this encouragement none of this would have happened."

"It varies a lot. Some companies implement the model for internal work and improvements; some do it to get in the photo."

Degree of consensus
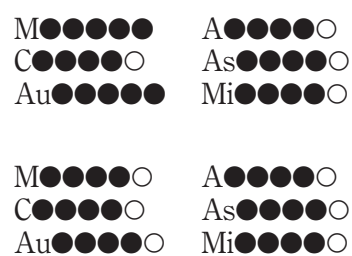

M०00००

Co0000

$\mathrm{Au} \bullet 000 \mathrm{O}$

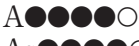

As

Mi९९९००

M०0000

Co००००

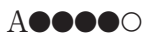

$\mathrm{Au}$

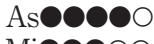

Mi॰c000

M०९०००

C०0000

A implementing ISO. The EFQM model was the next step."

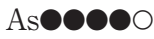

Mi९०0००

"The prizes and stamps have been well publicised, even over-publicised. A large number of companies understand that implementing these models is important for their image."

Notes: M: Managers; C: Consultants; Au: Auditors; A: Assessors, As: Academic specialists and Mi: Members of institutions

Source: Prepared by the authors

to be two types of companies: those that apply these models to improve company management, and those who do so to improve the company's quality image.

There is a very high degree of consensus on emphasising the importance of the implementation of the models on the company's market quality image. Taken together, according to some of the experts consulted, the image per se that the recognition associated with these models (whether certificates or awards) transmits is not static. In this respect, the economic-financial analogy seems clear: the value of the certificate or award is inversely proportional to the number of certificates or awards in circulation. It would seem, therefore, that the ISO 9000 standards are coming close to the decline stage, if we analyse their development from the point of view of the life cycles of management tools (see Marimón et al., 2004). We must wait and see whether the new version of the standard for 2000 will mean its reactivation, "a new wave of certifications", in the words of one expert consulted. The implementation of TQM models based on the EFQM model seems to be in a preliminary phase, one of great growth, and due to the great support it is receiving from different institutional bodies, for the moment, a more promising future can be predicted for it. We do think that these findings are really interesting and important for practitioners too, since they are deemed to be a very interested party of the diffusion process of QM systems and models[9].

Given the way things are, we believe that the bodies promoting and motivating quality (foundations, associations, certifying bodies, consultancies, etc.) should make a 
special effort to try to prevent further extension of the habit of using one of the many added values of the process of introducing a quality model - obtaining certificates or awards as an aim in itself - or in other words, quality as a mere advertising tool which means nothing more than short-term success, something that could have a negative bearing on the expansion of what has come to be known as the quality movement.

To our understanding, further empirical studies are necessary to analyse the real perceptions of the various agents (directing managers, middle managers, workers, consumers, suppliers, unions, consultancies, auditors, certifying bodies, public authorities, etc.) with regard to the different concepts, systems, models or tools related to quality. We do believe that from the academic world, there should be more in-depth analysis of the impact of management models on companies, and more empirical studies from a perspective that takes into account the holistic and multidimensional reality of companies should be carried out.

\section{Notes}

1. It must be remembered that the ISO 9000 regulations are based on the BS 5750 regulations developed by the UK standardisation body, the British Standards Institution in 1979.

2. This article was written as part of a research project titled "Impact of Quality Management on Spanish Companies" (SEC2003-06634) financed by the Ministry of Science and Technology within the aid programme for $\mathrm{R}+\mathrm{D}$ projects.

3. There are various QM introductory manuals which clarify many of these aspects. Among them, the following stand out: Dale, 2002; Moreno-Luzon et al., 2001; Llorens and Fuentes, 2001.

4. There have been several reviews of literature carried out at an international level, among which those by Ahire et al. (1995) stand out together with Sila's most recent review in which 347 articles published between 1989 and 2000 are analysed.

5. In addition to the research studies cited in the table, many others related to the same topic were carried out in earlier years. In the interests of brevity, we have chosen to only include a selection of the most relevant studies from the last seven years.

6. With extensive experience in the field of QM as both research specialists and programme and system implementation specialists.

7. Euskalit, Basque Foundation for Quality, is an organisation, which advocates management improvement and innovation by promoting the Total Quality culture in the Basque Country. The Knowledge Cluster is an association dedicated to promoting and supporting the development and use of management knowledge in the Basque Country.

8. We would like to take the opportunity to thank all the experts for their participation in the group and, especially, Euskalit for the assistance provided.

9. The Basque Country Public Administration has repeadely defended this point of view that underlines the goodness of the EFQM model as compared to the ISO 9000 (see, for example, the Basque Department of Industry, Agriculture and Fisheries, 1997).

\section{References}

Acharya, U.H. and Ray, S. (2000), "ISO 9000 certification in Indian industries: a survey", Total Quality Management, Vol. 11 No. 3, pp. 261-6.

Ahire, S.L., Landeros, R. and Golhar, D.Y. (1995), "Total quality management: a literature review and an agenda for future research", Production and Operations Management, Vol. 4 No. 3, pp. 227-306. 
IJQRM

23,7

824
Beattie, K.R. and Sohal, A.S. (1999), "Implementing ISO 9000: a study of its benefits among Australian organizations", Total Quality Management, Vol. 10 No. 1, pp. 95-106.

Boulter, L. and Bendell, T. (2002), "How can ISO 9000:2000 help companies achieve excellence? What the companies think", Measuring Business Excellence, Vol. 6 No. 2, pp. 37-41.

Boys, K., Karapetrovic, S. and Wilcock, A. (2004), "Is ISO 9004 a path to business excellence? Opinion of Canadian standards experts", International Journal of Quality \& Reliability Management, Vol. 21 No. 8, pp. 841-60.

Buttle, F. (1997), "ISO 9000: marketing motivations and benefits", International Journal of Quality \& Reliability Management, Vol. 14 No. 9, pp. 936-47.

Campbell, R. (1966), A Methodological Study of the Utilization of Experts in Business Forecasting, UCLA, Los Angeles, CA.

Carlsson, M. and Carlsson, D. (1996), "Experiences of implementing ISO 9000 in Swedish industry", International Journal of Quality \& Reliability Management, Vol. 13 No. 7, pp. 36-47.

Casadesús, M., Gimenez, G. and Heras, I. (2001), "Benefits of ISO 9000 implementation in Spanish industry”, European Business Review, Vol. 13, pp. 327-36.

Castells, M. (1999), "La era de la información. Economía, sociedad and cultura, Vol. 1. La sociedad red", Alianza Editorial, Madrid.

Dale, B.G. (2002), Managing Quality, 3rd ed., Blackwell Publishing, Oxford.

Denzin, N.K. and Lincoln, Y.S. (1994), Handbook of Qualitative Research, Sage, Thousand Oaks, CA.

Dimara, E., Skuras, D. and Tsekouras, K. (2004), "Strategic orientation and financial performance of firms implementing ISO 9000", International Journal of Quality \& Reliability Management, Vol. 21 No. 1, pp. 72-89.

Dootson, S. (1995), “An in-depth study of triangulation”, Journal of Advanced Nursing, Vol. 22, pp. 183-7.

Erel, E. and Ghosh, J.B. (1997), "ISO 9000 implementation in Turkish industry", International Journal of Operations \& Production Management, Vol. 17 No. 12, pp. 1233-46.

Gotzamani, K.D. and Tsiotras, G.D. (2002), "The true motives behind ISO 9000 certification: Their effect on the overall certification benefits and long term contribution towards TQM", International Journal of Quality, Vol. 19 No. 2, pp. 151-69.

Green, A. and Price, I. (2000), "Whither FM? Delphi study of the profession and the industry", Facilities, Vol. 18 No. 7, pp. 281-93.

Hardjono, Ten Have, S. and Ten have, W.D. (1997), The European Way to Excellence. How 35 European Manufacturing, Public and Service Organisations Make Use of Quality Management, Directorate-General III Industry, European Commission, Brussels.

Haversjö, T. (2000), "The financial effects of ISO 9000 registration for Danish companies", Managerial Auditing Journal, Vol. 15 No. 1, pp. 47-52.

Helmer, O. (1966), The Use of the Technique Delphi in Problems of Educational Innovation, The Rand Corporation, Santa Monica, CA.

Heras, I. (2001), La Gestión de la Calidad en las empresas vascas: estudio de la aplicación de ISO 9000 en las empresas de la CAPV, Serie Tesis Doctorales, Servicio de Publicaciones de la Universidad del País Vasco, Pais Vasco.

Heras, I., Casadesús, M. and Dick, G.P.M. (2002a), "ISO 9000 certification and the bottom line: a comparative study of the profitability of Basque region companies", Managerial Auditing Journal, Vol. 17 No. 1, pp. 72-8. 
Heras, I., Dick, G.P.M. and Casadesús, M. (2002b), "ISO 9000 registration's impact on sales and profitability: a longitudinal analysis of performance before and after accreditation", International Journal of Quality \& Reliability Management, Vol. 19, pp. 774-91.

Huarng, F., Horng, C. and Chen, C. (1999), "A study of ISO 9000 process, motivation and performance”, Total Quality Management, Vol. 10 No. 7, pp. 1009-25.

Idris, M.A., McEwan, W. and Belavendram, N. (1996), "The adoption of ISO 9000 and total quality management in Malaysia”, The TQM Magazine, Vol. 8 No. 5, pp. 65-8.

Jones, R., Arndt, G. and Kustin, R. (1997), "ISO 9000 amongst Australian companies: impact of time and reasons for seeking certification on perceptions of benefits received", International Journal of Quality \& Reliability Management, Vol. 14 No. 7, pp. 650-60.

Klassen, R.D. and Whybark, D.C. (1994), "Barriers to the management of international operations", Journal of Operations Management, Vol. 11 No. 4, pp. 385-96.

Landeta, J. (1999), El método Delph, Ariel, Barcelona.

Lee, K.S. and Palmer, E. (1999), "An empirical examination of ISO 9000-registered companies in New Zealand”, Total Quality Management, Vol. 10 No. 6, pp. 887-99.

Leonard, D. and Mcadam, R. (2002), "The strategic impact and implementation of TQM", The TQM Magazine, Vol. 14 No. 1, pp. 51-60.

Leung, H.K.N., Chan, K.C.C. and Lee, T.Y. (1999), "Costs and benefits of ISO 9000 series: a practical study", International Journal of Quality \& Reliability Management, Vol. 16 No. 7 , pp. 675-91.

Linstone, A. and Turoff, M. (1975), The Delphi Method: Techniques and Applications, Addison-Wesley, Reading, MA.

Linstone, A. and Turoff, M. (2002), The Delphi Method: Technique and Applications, available at: www.is.njit.edu/pubs/delphibook/

Lipovatz, D., Stenos, F. and Vaka, A. (1999), "Implementation of ISO 9000 quality systems in Greek enterprises”, International Journal of Quality \& Reliability Management, Vol. 16 No. 6, pp. 534-51.

Llorens, F.J. and Fuentes, M. (2001), Calidad total: fundamentos e implantacion, Editorial Piramide, Madrid.

MacCarthy, B.L. and Atthirawong, W. (2003), "Factors affecting location decisions in international operations: a Delphi study", International Journal of Operations \& Production Management, Vol. 23 No. 7, p. 794.

Marimón, F., Heras, I. and Casadesús, M. (2004), La difusión internacional de las normas ISO 9000 e ISO 14000, Congreso nacional de ACEDE 2004, Murcia.

Mathews, B.P., Ueno, A., Kekale, T., Repka, M., Pereira, Z.L. and Silva, G. (2001), "European quality management practices: the impact of national culture", International Journal of Quality \& Reliability Management, Vol. 18, pp. 692-707.

Meegan, S.T. and Taylor, W.A. (1997), "Factors influencing a successful transition from ISO 9000 to TQM: the influence of understanding and motivation", International Journal of Quality \& Reliability Management, Vol. 14 No. 2, pp. 100-17.

Moreno-Luzon, M.D., Peris, F.J. and González, T. (2001), Gestion de la calidad y diseño de organizaciones, Editorial Pearson educacion, Madrid.

Nottingham Trent University (1998), "UK companies register for efficiency", Quality Digest, Vol. 29 No. 6, January, pp. 43-8.

Ray, P.K. and Sahu, S. (1990), "Productivity management in India: a Delphi study", International Journal of Operations \& Production Management, Vol. 10 No. 5, p. 25. 
IJQRM

23,7

826
Reid, N. (1988), "The Delphi technique: its contribution to the evaluation of professional practice", in Ellis, R. (Ed.), Professional Competence and Quality Assurance in the Caring Professions, Chapman-Hall, London.

Rodríguez Antón, J.M., Rubio, L., Esteban, C. and Laguna, M. (2004), Formulación de un Modelo de Capital Intelectual Hotelero: Aplicación a los hoteles de lujo de Madrid, Congreso nacional de ACEDE 2004, Murcia.

Sackman, H. (1975), Delphi Critique: Expert Opinions, Forecasting, and Group Process, D.C. Heath, Lexington, MA.

Salaheldin, S.I. (2003), "The implementation of TQM strategy in Egypt: a field-force analysis", The TQM Magazine, Vol. 15 No. 4, pp. 266-74.

Santos, G., Lopes, A. and Cruz, V. (1996), "Impact of quality certification in SMEs", 40th Annual EOQ-Congress, Vol. 1, Berlin.

Singels, J., Ruel, G. and Van de Water, H. (2001), "H. ISO 9000 series - Certification and performance”, International Journal of Quality \& Reliability Management, Vol. 18 No. 1, pp. 62-75.

Sohal, A.S. and Terziovski, M. (2000), "TQM in Australian manufacturing: factors critical to success", International Journal of Quality \& Reliability Management, Vol. 17 No. 2, pp. 158-68.

Sun, H. (1999), "Diffusion and contribution of total quality management: an empirical study in Norway", Total Quality Management, Vol. 10 No. 6, pp. 901-14.

Tang, S.L. and Kam, C.W. (1999), "A survey of ISO 9001 implementation in engineering consultancies in Hong Kong", International Journal of Quality \& Reliability Management, Vol. 16 No. 6, pp. 562-74.

Taylor, W.A. (1995), "Organizational differences in ISO 9000 implementation practices", International Journal of Quality \& Reliability Management, Vol. 12 No. 7, pp. 10-27.

Van der Wiele, T., Dale, B. and Williams, R. (2000), "ISO 9000 series and excellence models: fad to fashion to fit", Journal of General Management, Vol. 25 No. 3, pp. 50-66.

Wayhan, V.B., Kirche, E.T. and Khumawala, B.M. (2002), "ISO 9000 certification: the financial performance implications”, Total Quality Management, Vol. 13 No. 2, pp. 217-31.

Withers, B.E. and Ebrahimpour, M. (1996), "An examination of ISO 9000 registration practices of American, German and Japanese firms operating in the USA", International Journal of Quality \& Reliability Management, Vol. 13 No. 7, pp. 8-22.

Woudenberg, F. (1991), "An evaluation of Delphi”, Technological Forecasting and Social Change, Vol. 40, pp. 131-50.

Yusof, S.M. and Aspinwall, E. (2001), "Case studies on the implementation of TQM in the UK automotive SMEs", International Journal of Quality \& Reliability Management, Vol. 18 No. 7, pp. 722-44.

\section{Further reading}

Bello, L., Vázquez, R. and Trespalacios, J.A. (1996), Investigación de mercado and estrategias de marketing, Ed. Civitas, Madrid.

Brown, A. and Van der Wiele, T. (1996), "A typology of approaches to ISO certification and TQM", Australian Journal of Management, Vol. 21 No. 1, p. 57.

Casadesús, M. and Gimenez, G. (2000), "The benefits of the implementation of the ISO 9000 standard: empirical research in 288 Spanish companies", The TQM Magazine, Vol. 12, pp. 432-41. 
Escanciano, C., Fernandez, E. and Vazquez, C. (2001), "ISO 9000 certification and quality management in Spain: results of a national survey", The TQM Magazine, Vol. 13 No. 3, pp. 192-200.

Gunnlaugsdottir, J. (2002), "The quality must be on record: a survey of organisations having an ISO 9000 certification in Iceland", Records Management Journal, Vol. 12 No. 2, pp. 40-7.

Gustafsson, R., Klefsjo, B., Berggren, E. and Granfors-Wellemets, U. (2001), "Experiences from implementing ISO 9000 in small enterprises - a study of Swedish organisations", The TQM Magazine, Vol. 13 No. 4, pp. 232-46.

Llopis, J. and Tari, J.J. (2003), "The importance of internal aspects in quality improvement", International Journal of Quality \& Reliability Management, Vol. 20 No. 3, pp. 304-24.

Martínez, C., Balbastre, F. and Escrig, A.B. (2001), "La evaluación en el marco de la gestión de la calidad: un análisis en función del enfoque utilizado", Revista Europea de Dirección y Economía de la Empresa, Vol. 10 No. 1, pp. 37-54.

Sila, I. and Ebrahimpour, M. (2002), "An investigation of the total quality management survey based research published between 1989 and 2000: a literature review", International Journal of Quality \& Reliability Management, Vol. 19 No. 7, pp. 902-70.

Silva, A. (1997), The Added Value and Credibility of Certification of Quality Systems in the European Union, Compilation of quality series documents, Quality series, The European Quality Promotion Policy, European Commission, DGIII - Industry, Brussels.

Silva, A. and Giannuolo, G. (1996), The Social impact of Quality Policy Implementation on European Industry, Compilation of quality series documents, Quality series, The European Quality Promotion Policy, European Commission, DGIII - Industry, Brussels.

Terziovski, M., Power, D. and Sohal, A.S. (2003), "The longitudinal effects of the ISO 9000 certification process on business performance", European Journal of Operational Research, Vol. 146 No. 3, pp. 580-95.

Vloeberghs, D. and Bellens, J. (1996), "Implementing the ISO 9000 standards", Quality Progress, Vol. 29 No. 6, pp. 43-8.

Yong, J. and Wilkinson, A. (1999), "The state of total quality management: a review", International Journal of Human Resource Management, Vol. 10 No. 1, pp. 137-61.

To purchase reprints of this article please e-mail: reprints@emeraldinsight.com Or visit our web site for further details: www.emeraldinsight.com/reprints 